\title{
PENGARUH KONSENTRASI KEPEMILIKAN DAN KOMPETENSI DEWAN KOMISARIS PADA KONSERVATISMA AKUNTANSI
}

\author{
Ni Made Dwi Ratnadi dan I Gusti Ketut Agung Ulupui \\ Fakultas Ekonomi dan Bisnis Universitas Udayana \\ Email:madedwiratnadi@yahoo.com dan ulupui@yahoo.com
}

\begin{abstract}
The purpose of this study is to examine the effect of concentration of ownership and the competence of the commissioners on accounting conservatism. Concentration of ownership is proxied by substantial ownership by internal shareholders and ownership by external shareholders. The competence of the board of commissioners in proxied by the company's specific competence, competence commissioners in accounting or finance and competence in corporate governance. Accounting conservatism measured by accrual models. The population is all companies listed on the Indonesian Stock Exchange in 2013 and 2014. The sample period is determined based on probability sampling method with stratified random sampling technique. The number of samples analyzed a total of 120 observations. The analyzed data is secondary data, taken from the company's annual report samples. Multiple linear regression techniques were used to analyze the data. The results showed that the concentration of ownership on internal shareholders negative effect on the level of accounting conservatism. The concentration ofexternal ownership have negative effect on the level of accounting conservatism. The company-specific competencies commissioners, competence in the field of accounting / finance commissioners and competence of corporate governance has no effect on accounting conservatism.
\end{abstract}

Keywords: Ownership concentration, the competence of the commissioners, accounting conservatism

Abstrak: Tujuan penelitian ini untuk menguji pengaruh konsentrasi kepemilikan dan kompetensi dewan komisaris pada konservatisme akuntansi. Konsentrasi kepemilikan diproksikan dengan kepemilikan substansial oleh pemegang saham internal dan kepemilikan oleh pemegang saham eksternal. Kompetensi dewan komisaris di proksikan dengan kompetensi spesifik perusahaan. Populasi adalah seluruh perusahaan manufaktur yang terdaftar di Bursa Efek Indonesia periode 2013 dan 2014. Sampel ditentukan berdasarkan metoda probability sampling dengan teknik stratified random sampling. Jumlah sampel yang dianalisis sebanyak 120 amatan. Data yang dianalisis adalah data sekunder, dikutip dari laporan tahunan perusahaan sampel. Teknik regresi linear berganda digunakan untuk menganalisis data. Hasil penelitian menunjukkan bahwa konsentrasi kepemilikan pada pemegang saham internal berpengaruh negatif pada tingkat konservatisma akuntansi. Konsentrasi kepemilikan pada pihak eksternal berpengaruh negatif pada tingkat konservatisma akuntansi. Kompetensi spesifik perusahaan anggota dewan komisaris, kompetensi dibidang akuntansi/keuangan anggota dewan komisaris dan kompetensi tata kelola perusahaan tidak berpengaruh pada konservatisme akuntansi.

Kata kunci: Konsentrasi Kepemilikan, Kompetensi Dewan Komisaris, Konservatisma Akuntansi 


\section{PENDAHULUAN}

Konservatisme akuntansi merupakan prinsip penilaian yang memengaruhi praktik akuntansi selama beberapa abad dan merupakan konvensi penting dalam pelaporan keuangan (Sterling, 1967; Basu,1997). Prinsip ini diperlukan untuk mengurangi sikap optimistis manajemen dalam melaporkan aktiva dan laba. Konservatisma akuntansi merupakan suatu sikap hati-hati (prudent reaction) dalam menghadapi ketidakpastian yang melekat dalam perusahaan serta mencoba memastikan bahwa ketidakpastian dan risiko yang inheren dalam lingkungan bisnis sudah cukup dipertimbangkan. Implikasinya terhadap pelaporan keuangan adalah mengakui biaya atau kerugian yang kemungkinan besar akan terjadi, tetapi tidak mengakui lebih dahulu pendapatan atau untung yang akan datang walaupun kemungkinan terjadinya besar (Suwardjono, 2005: 245). Akibatnya, aset dan laba yang dilaporkan oleh perusahaan cenderung tersaji-kurang (understated).

Basu (1997), Givoly dan Hayn (2000), Watts (2003a), dan Ball dan Shivakumar (2005) menyatakan bahwa konservatisma merujuk pada pengakuan rugi (bad news) lebih cepat dibandingkan dengan pengakuan laba (good news). Kondisi ini menyebabkan konservatisma akuntasi dikritik oleh beberapa pengguna laporan keuangan. Perusahaan yang menerapkan konservatisma akuntansi dikatakan oleh Penman dan Zhang (2008) memiliki kualitas laba yang rendah. Adopsi International Financial Accounting Reporting Standards (IFRS) sebagai pedoman dalam penyajian laporan keuangan merupakan bentuk penolakan dan kritik terhadap konservatisma akuntansi. IFRS menggunakan prinsip nilai wajar yang berfokus pada relevansi penyajian informasi akuntansi. Akan tetapi, Hille (2011) membuktikan bahwa tidak ada perbedaan konservatisma akuntansi sebelum dan sesudah penerapan IFRS pada perusahaan-perusahaan di Eropa.

Ada empat alasan yang digunakan untuk menjelaskan mengapa konservatisme akuntansi dianggap penting, yaitu alasan pengontrakan, litigasi pemegang saham, perpajakan, dan regulasi akuntansi (Watts, 2003a). Berdasarkan penjelasan pengontrakan, diketahui bahwa konservatisma akuntansi menyebabkan semakin kecil jumlah laba yang dikendalikan oleh manajemen sehingga konservatisma berperan sebagai kendali atas kecenderungan manajemen untuk menikmati sebanyak mungkin laba perusahaan.

Pembatasan ini diperlukan, baik oleh investor maupun kreditor, bahkan oleh manajemen sebagai bentuk penjaminan, serta semua pihak yang melakukan kontrak dengan perusahaan karena mereka menggunakan angka-angka akuntansi untuk mengurangi biaya agensi (Ahmed et al., 2002; Watts, 2003a; Ahmed dan Duellman, 2006; Zhang, 2008; Nikolaev, 2010). Penerapan konservatisma akuntansi dapat mengatasi moral hazard oleh manajemen karena pihak-pihak yang terlibat kontrak dengan perusahaan memiliki informasi asimetris, payoff asimetris, horizon waktu terbatas, dan kewajiban yang terbatas. Di samping itu, juga dapat membatasi perilaku oportunistik manajer berkait dengan insentif pembayaran berlebihan kepada manajer dan membatasi pembayaran oportunistik pada pihak lain, seperti pemegang saham (Watts, 2003a).

Claeesens et al (2000), Febrianto, (2005),Siregar (2006), Sanjaya (2010), Ratnadi et al. (2013) menyakatan bahwa belum terdapat pemisahan yang jelas antara kepemilikan saham dan kontrol pada perusahaan yang terdaftar di Bursa Efek Indonesia. Kebanyakan perusahaan masih dimiliki oleh keluarga pendiri dan posisi manajer dipegang oleh pemegang saham mayoritas atau dari kalangan keluarga. Akibatnya, para manajer perusahaan publik hanya menjadi kepanjangan tangan pemegang saham terbesar yang masih dikendalikan oleh keluarga tertentu. Walaupun kondisi ini dapat mengurangi 
konflik keagenan antara pemegang saham dan manajemen. Akan tetapi, dapat menimbulkan konflik keagenan antara pemegang saham mayoritas dan minoritas. Teori akuntansi positif menyarankan konservatisma akuntansi dapat mengontrol perilaku oportunistik manajer termasuk juga perilaku pemegang saham pengendali.

Konservatisme akuntansi merupakan cara yang penting dalam mengatasi konflik keagenan dan jika diterapkan secara efektif dapat meningkatkan nilai perusahaan, dan akhirnya mampu melindungi kepentingan pemegang saham minoritas (Watts, 2003a). Fama dan Jensen \& Meckling (1986) menyarankan bahwa dewan komisaris merepresentasikan bentuk pengendalian internal yang paling tinggi untuk memonitor manajemen puncak termasuk CEO. Ada empat karakteristik dewan komisaris yaitu komposisi dewan, ukuran dewan, kompetensi, CEO duality merupakan atribut dari dewan. Jensen (1993) menyatakan bahwa empat faktor inilah yang memengaruhi peranan dewan dalam memonitor manajer.

Kompetensi dewan komisaris merupakan faktor yang sangat penting, karena dewan komisaris yang memiliki pemahaman yang baik atas operasi bisnis dapat mereviu laporan keuangan secara efektif (Lanfranconi dan Robertson, 2002). Ada tiga tipe kompentensi dewan komisaris yaitu kompetensi spesifik perusahaan, kompetensi di bidang akuntansi/ keuangan dan kompetensi tata kelola perusahaan. Berdasarkan latar belakang masalah, maka rumusan masalah penelitian ini adalah: (1) Apakah konsentrasi kepemilikan berpengaruh pada konservatisma akuntansi; (2) Apakah Kompetensi dewan komisaris berpengaruh pada konservatima akuntansi.

Penelitian ini bertujuan untuk menguji dan menganalisis pengaruh kepemilikan internal dan eksternal pada konservatisma akuntansi dan untuk menguji dan menganalisis pengaruh kompetensi anggota dewan komisaris pada konservatisma akuntansi. Penelitian ini diharapkan memiliki manfaat yaitu dapat menambahkan resource dependence theory untuk melengkapi teori keagenan. Hasil penelitian ini diharapkan dapat memperkuat pemahaman tentang teori tersebut dalam menjelaskan perilaku praktisi tata kelola perusahaan dan laporan keuangan pada perusahaan publik di Indonesia. Penelitian ini juga diharapkan dapat mendukung teori akuntansi positif yang menyatakan bahwa konservatisma akuntansi merupakan salah satu cara untuk mengurangi konflik keagenan.

\section{KAJIAN TEORI}

Pengaruh Konsentrasi Kepemilikan Saham Terhadap Konservatisma Akuntansi. Konsentrasi kepemilikan saham menyebabkan pemegang saham memiliki akses atas informasi privat sehingga dapat mengurangi konflik keagenan antara pemegang saham dan manajemen. Akibatnya, konsentrasi kepemilikan akan dapat mengurangi kualitas laporan keuangan. Pemegang saham mayoritas tidak terlalu berkepentingan atas konservatisma akuntansi. Mereka tidak memerlukan informasi yang disajikan dalam laporan keuangan karena sudah memiliki informasi privat (Dargenidou et al.,2007). Argumen entrenchement effect dan substitution effect menyatakan bahwa pemegang saham mayoritas menyebabkan laporan keuangan disajikan kurang konservatif karena pemegang saham mayoritas tidak memerlukan alat mekanisme tata kelola untuk mengendalikan perilaku manajer atau pemegang saham mayoritas dapat memonitor secara langsung manajemen. Akan tetapi, pemegang saham minoritas memerlukan informasi tentang perusahaan, sehingga mereka memerlukan pengungkapan yang lebih banyak dalam pelaporan keuangan (Yeo et al., 2002). Banyaknya informasi yang diungkapkan dapat mengurangi earnings management 
(Azofra et al., 2003). Oleh karena, pentingnya konservatisma akuntansi bagi kelompok pemegang saham berbeda, maka dalam penelitian ini konsentrasi kepemilikan dibedakan menjadi konsentrasi kepemilikan oleh pihak internal perusahaan (insiders) dan kepemilikan pihak eksternal perusahaan (outsiders). Berkenaan dengan hal tersebut, maka hipotesis penelitian dikembangkan seperti berikut ini.

H1a: Semakin besar proporsi kepemilikan saham terkonsentrasi pada pihak internal perusahaan menyebabkan semakin rendah tingkat konservatisma akuntansi.

H1b. Semakin besar proporsi kepemilikan saham terkonsentrasi pada pihak eksternal perusahaan menyebabkan semakin tinggi tingkat konservatisma akuntansi.

Pengaruh kompetensi dewan komisaris terhadap konservatisma akuntansi. Ada tiga kompetensi dewan komisaris yang dapat berkontribusi pada effektivitas tata kelola perusahaan (Yunos et al, 2010), yaitu kompetensi spesifik-perusahaan, kompetensi dalam bidang keuangan dan kompetensi dalam tata kelola perusahaan. Kompetensi spesifik perusahaan merujuk pada pengetahuan yang dimiliki oleh dewan komisaris atas perusahaan karena lamanya mereka bekerja di perusahaan tersebut. Kompetensi di bidang akuntansi/ keuangan merujuk pada pengetahuan akuntansi yang dimiliki oleh dewan komisaris yang memungkinkan mereka untuk memahami proses dalam penyajian laporan keuangan, dan dapat membuat keputusan untuk meningkatkan kualitas laporan keuangan. Kompetensi dalam bidang tata kelola merupakan pengalaman dewan komisaris dalam mengelola perusahaan dilihat dari jabatan dewan komisaris pada perusahaan lain, sehingga semakin memperdalam pengetahuan mereka dalam memecahkan masalah yang dihadapi.

Beberapa penelitian sebelumnya membuktikan bahwa lamanya seorang dewan komisaris bekerja pada perusahaan mengurangi earnings management (Dedard et al., 2004; Peasnell et al., 2005). Hal ini mengimplikasikan bahwa dewan direksi lebih kompeten dalam membatasi manipulasi laba. Semakin lama seorang dewan komisaris bekerja disuatu perusahaan menurut (Chang, 2009) dapat mengurangi timbulnya kesulitan finansial (financial distress).

Dewan komisaris yang memiliki kompetensi dalam bidang akuntansi/ keuangan, mampu lebih baik dalam memonitor, sehingga dapat lebih efektif dalam meningkatkan kualitas laporan keuangan (Lanfranconi dan Robertson, 2002; MCMullen dan Raghunandan, 1996; Rose dan Rose, 2008). Dewan komisaris yang memiliki jabatan rangkap pada perusahaan lain, memungkinkan mereka memiliki banyak pengalaman dan pengetahuan tentang tata kelola perusahaan. Akan tetapi, mereka tidak dapat mengaplikasikan pengetahuannya secara efektif pada suatu perusahaan karena sangat sibuk dan memiliki waktu yang terbatas. Konsisten dengan argumen tersebut, Haniffs dan Hudaib (2006) menyatakan bahwa dewan komisaris yang memiliki jabatan rangkap pada perusahaan lain menyebabkan rendahnya kinerja perusahaan, rendahnya konservatisma (Ahmed dan Duellman, 2006), dan tingginya earnings management (Sarkar et al., 2008). Berdasarkan bukti tersebut dapat dinyatakan lamanya seorang dewan komisaris bekerja di satu perusahaan dan memiliki kompetensi dibidang akuntansi/ keuangan merupakan atribut kuatnya tata kelola perusahaan, sehingga menyebabkan meningkatnya konservatisma akuntansi, sebagai dasar untuk membantu mereka dalam peran pengawasan. Berdasarkan hal tersebut, hipotesis penelitian yang dikembangkan adalah seperti berikut ini.

H2a: Kompetensi dewan komisaris yang spesifik berpengaruh positif pada konservatisma akuntansi. 
H2b. Semakin tinggi proporsi dewan komisaris yang memiliki kompetensi dalam bidang akuntansi/keuangan, menyebabkan semakin tinggi tingkat konservatisma akuntansi.

H2c: Semakin tinggi proporsi dewan komisaris yang memiliki kompetensi tata kelola perusahaan semakin rendah tingkat Konservatisma akuntansi

\section{METODE}

Populasi dan Sampel Penelitian. Populasi penelitian ini adalah perusahaan manufaktur yang terdaftar di Bursa efek Indonesia tahun 2013 dan 2014. Alasan pemilihan perusahaan manufaktur agar tidak terjadi bias akibat karakteristik perusahaan yang berbeda. Sampel ditentukan dengan metoda penyampelan probabilitas (probability sampling). Metoda penyampelan probabilitas merupakan metoda pemilihan sampel, yaitu setiap anggota populasi mempunyai peluang yang sama untuk dipilih menjadi anggota sampel. Teknik pengambilan sampel dengan cara stratifikasi (stratified random sampling). Ukuran sampel ditentukan dengan menggunakan rumus Slovin, dengan batas kesalahan sebesar 10 persen. Rumus Slovin digunakan untuk menentukan sampel minimal yang dibutuhkan. Adapun formulasi yang digunakan seperti berikut ini.

$$
\mathrm{n}=\frac{\mathrm{N}}{1+\mathrm{Ne}^{2}}
$$

Keterangan: $\mathrm{n}$ = ukuran sampel; $\mathrm{N}=$ ukuran populasi; $\mathrm{E}=$ kelonggaran ketidak telitian karena kesalahan pengambilan sampel yang dapat ditolerir.

Pengumpulan Data. Teknik pengumpulan data adalah teknik pengumpulan data arsip atau dokumentasi. Salah satu bentuk pengumpulan data arsip adalah data sekunder. Data sekunder dalam penelitian ini diperoleh dari Laporan Keuangan Auditan yaitu laporan tahunan meliputi laporan rugi laba, neraca, dan laporan arus kas tahun 2013 dan 2014.

Variabel Penelitian dan Pengukuran. Variabel dependen penelitian ini adalah tingkat konservatisma akuntansi, sedangkan variabel independennya adalah konsentrasi kepemilikan dan kompetensi dewan dewan komisaris. Pertama. Konservatisma akuntansi mengakibatkan laba yang terakumulasi dari tahun ke tahun cenderung lebih kecil daripada arus kas operasi, sehingga akumulasi akrual menjadi negatif. Pengukuran tingkat konservatisma akuntansi dalam penelitian ini mengikuti model akrual yang dikembangkan oleh Givoly dan Hayn (2000). Model ini merupakan pengukuran spesifik perusahaan ( $a$ firm-specific measures). Tingkat konservatisma akuntansi diukur dengan akrual total dikurangi arus kas dari aktivitas operasi dideplesi dengan total aset akhir tahun. Pengukuran konservatisma akuntansi dengan model ini akan bernilai negatif jika perusahaan menerapkan konservatisma akuntansi. Agar tingkat konservatisma akuntansi (TKA) mencerminkan nilai makin konservatif, maka hasil perhitungan tingkat konservatisma akuntansi dikalikan dengan minus 1 (-1). Berikut ini adalah formula yang digunakan.

$$
\mathrm{TKA}=\frac{\mathrm{AAC}_{\mathrm{it}}-\mathrm{AKO}_{\mathrm{it}}}{\mathrm{TA}_{\mathrm{it}}} x-1 .
$$

Keterangan: TKA = Tingkat konservatisma akuntansi; $\mathrm{AAC}_{\mathrm{it}}=$ Akrual yaitu laba bersih sebelum item extraordinary ditambah depresiasi dan amortisasi perusahaan i pada 
perioda t; $\mathrm{AKO}_{\mathrm{it}}=$ Arus kas dari aktivitas operasi perusahaan i pada tahun t; $\mathrm{TA}_{\mathrm{it}}=$ Total Aktiva perusahaan i pada akhir tahun $\mathrm{t}$

Kedua. Konsentrasi kepemilikan merupakan persentase kepemilikan saham perusahaan yang beredar oleh pemegang saham substansial. Penelitian ini mengelompokkan konsentrasi kepemilikan saham menjadi dua kelompok yaitu kepemilikan terkonsentrasi pada pihak internal dan konsentrasi kepemilikan pada pihak eksternal. Konsentrasi kepemilikan pada pihak internal (KPI) diukur dengan persentase kepemilikan saham oleh eksekutif dan pihak non eksekutif yang tidak independen (kepemilikan keluarga). Konsentrasi kepemilikan oleh pihak eksternal diukur dengan persentase kepemilikan saham oleh pihak luar yang independen dari manajemen perusahaan. Ketiga. Kompetensi Dewan komisaris diproksikan dengan 3 variabel yaitu kompetensi spesifik perusahaan (Board Tenure-BT), kompetensi Dewan komisaris di bidang keuangan (Board Financial Expertise- BF) dan kompetensi tata kelola dewan komisaris (Multiple Derectorships-MD). BT diukur dengan tahun masa kerja anggota dewan komisaris pada satu perusahaan. BF diukur dengan persentase anggota dewan komisaris yang memiliki pendidikan dibidang akuntansi/keuangan. MD diukur dengan proporsi anggota dewan komisaris yang bekerja pada perusahaan lain selain perusahaan yang diteliti. Keempat. Variabel kontrol dalam penelitian ini adalah ukuran perusahaan yang diukur dengan total aktiva akhir periode akuntansi. Semakin besar perusahaan akan menghadapi biaya politik yang tinggi, sehingga mereka cenderung menerapkan akuntansi konservatif untuk menghindari biaya politik (Watt dan Zimmerman, 1986).

Teknik Analisis. Teknik analis data yang digunakan dalam penelitian ini adalah regresi linear berganda dengan formula seperti berikut ini.

$$
\mathrm{TKA}=\alpha+\beta_{1} \mathrm{KPI}_{\mathrm{it}}+\beta_{2} \mathrm{KPE}_{i t}+\beta_{3} B T_{i t}+\beta_{4} B F_{i t}+\beta_{5} B M_{i t}+B_{6} T A_{i_{t}}+\varepsilon_{i t}
$$

\section{Keterangan:}

TKA = Tingkat konservatisma akuntansi; $\mathrm{KPI}_{\mathrm{it}}=$ Konsentrasi kepemilikan internal perusahaan i pada tahun $\mathrm{t}$; $\mathrm{KPE}_{i \mathrm{it}}=$ Konsentrasi kepemilikan eksternal perusahaan i pada tahun $\mathrm{t}$; $\mathrm{BT}$ it $=$ Kompetensi spesifik perusahaan anggota dewan komisaris.i tahun $\mathrm{t}$; $\mathrm{BF}_{\text {it }}$ $=$

Kompetensi Dewan direksi dibidang keuangan perusahaan i pada tahun t; $\mathrm{BM}$ it $=$ Kompetensi Anggota dewan direksi yang merangkan jabatan pada perusahaan i pada tahun $\mathrm{t} ; \mathrm{TA}_{\mathrm{it}}=$ Total aktiva i pada tahun $\mathrm{t}$ yang di ln-kan dalam proses analisis; $\alpha=$ merupakan konstanta; iit = error term perusahaan i pada tahun $\mathrm{t}$

Alat pengujian data yang menggunakan model statistik regresi berganda dengan metode OLS mensyaratkan agar dilaksanakan pengujian asumsi klasik atau asumsi model.

\section{HASIL DAN PEMBAHASAN}

Sampel penelitian adalah perusahaan manufaktur yang terdaftar di Bursa Efek Indonesia 2013 dan 2014. Total perusahaan manufaktur yang terdaftar di Bursa Efek Indonesia sebanyak 141 perusahaan. Sampel ditentukan dengan metode probability sampling dengan tehnik statified random sampling berdasarkan sektor industri perusahaan manufaktur. Ukuran sampel minimal ditentukan berdasarkan rumus Slovin, diperoleh sebanyak 58 perusahaan untuk satu tahun amatan, dalam penelitian ini digunakan 60 perusahaan. Data yang dikutip dalam penelitian ini selama dua tahun amatan yaitu tahun 
2013 dan 2014, sehingga jumlah amanat sebanyak 120. Jumlah amatan untuk tiap-tiap sektor industri disajikan pada Tabel 1.

Tabel 1. Jumlah Amatan Tiap-Tiap Sektor Industri Manufaktur

\begin{tabular}{lc}
\hline Keterangan & Jumlah Amatan \\
\hline Sektor Industri dasar dan Kimia & 55 \\
Sektor Aneka Industri & 33 \\
Sektor Industri Barang Dan Jasa & 32 \\
\hline Total Amatan Tahun (2013 -2014) & 120 \\
\hline
\end{tabular}

Deskripsi Variabel Penelitian. Deskripsi nilai minimum, nilai maksimum, nilai rata-rata dan deviasi standar tiap-tiap variabel penelitian secara ringkas disajikan pada Tabel 2.

Tabel 2. Hasil Uji Statistik Deskriptif

\begin{tabular}{lrrrrr}
\hline Variabel ${ }^{*}$ & $\begin{array}{c}\text { Jumlah } \\
\text { Amatan }\end{array}$ & $\begin{array}{c}\text { Nilai } \\
\text { Minimum }\end{array}$ & $\begin{array}{c}\text { Nilai } \\
\text { Rata-Rata }\end{array}$ & $\begin{array}{c}\text { Nilai } \\
\text { Maksimum }\end{array}$ & $\begin{array}{c}\text { Deviasi } \\
\text { Standar }\end{array}$ \\
\hline TKA & 120 & $-0,455$ & $-0,028$ & 0,228 & 0,096 \\
KPI(\%) & 120 & 0,000 & 25,60 & 98,10 & 34,90 \\
KPE(\%) & 120 & 0,000 & 43,70 & 100 & 41,70 \\
BT (tahun) & 120 & 1,000 & 11,324 & 40,000 & 7,880 \\
BF(\%) & 120 & 0,000 & 62,50 & 100 & 26,50 \\
BM (\%) & 120 & 0,000 & 63,40 & 100 & 31,00 \\
TA (dalam & & & & & \\
jutaan & 120 & 62.602 & 236.029 .000 & $8.076 .086,99$ & $29.736 .494,26$ \\
rupiah) & & & & & \\
\hline
\end{tabular}

*) TKA = Tingkat Konservatisma Akuntansi; KPI = Konsentrasi Kepemilikan Interen; $\mathrm{KPE}=$ Konsentrasi Kepemilikan Eksternal; $\mathrm{BT}=$ kompetensi spesifik perusahaan (lamanya dewan komisaris bekerja pada perusahaan); BF= Kompetensi Dewan Komisaris pada Bidang Akuntansi/Keuangan; BM= Kompetensi tata kelola dewan komisaris (jabatan rangkap dewan komisaris pada perusahaan lain; TA= Total Aktiva.

Berdasarkan Tabel 2 nilai rata-rata tingkat konservatisma akuntansi sebesar -0,028, artinya perusahaan manufaktur cenderung konservatif dalam menyajikan laporan keuangan, apabila diukur dengan konservatisma akuntansi berbasis (accrual-based conservatism). Rata-rata persentase kepemilikan saham beredar perusahaan oleh pihak manajemen dan anggota keluarganya adalah 25,60 persen dari jumlah lembar saham yang beredar. Rata-rata besarnya konsentrasi kepemilikan oleh pihak eksternal sebesar 43,70 persen. Lama rata-rata seorang dewan komisaris menjabat pada sebuah perusahaan adalah 11 tahun 4 bulan. Sedangkan paling lama masa kerja dewan komisaris di sebuah perusahaan 40 tahun. Rata-rata 62,50 persen anggota dewan komisaris memiliki kompetensi di bidang akuntansi dan keuangan dan 63,40 anggota dewan komisaris memiliki jabatan rangkap pada perusahaan lain. Nilai rata-rata total aktiva akhir tahun perusahaan sebesar Rp 236.029.000 Juta.

Hasil Uji Asumsi Klasik. Uji asumsi klasik yang dilakukan adalah uji normalitas, autokorelasi, multikolinearitas dan heteroskedastisitas. Hasil uji normalitas dengan menggunakan uji Kolmogorov-Smirnov menunjukkan data berdistribusi normal. Nilai 
Kolmogorov-Smirnov Z sebesar 1,501 dengan nilai Asymp. Sig. (2-tailed) 0,329 >0,05. Gejala multikolinearitas diuji dengan menggunakan nilai variance inflation factor (VIF) tiap-tiap variabel. Hasil pengujian menunjukkan bahwa semua variabel independen memiliki nilai VIF di bawah 10 dan tidak ada nilai tolerance di bawah 0,10, maka tidak ada masalah multikolinearitas. Hasil pengujian asumsi klasik selain uji heteroskedastisitas di sajikan pada Tabel 3.

Tabel 3. Hasil Uji Asumsi Klasik

\begin{tabular}{|c|c|c|c|c|}
\hline \multirow[b]{2}{*}{ Variabel } & \multicolumn{2}{|c|}{ Multikolinearitas } & \multirow{2}{*}{$\begin{array}{l}\text { Normalitas } \\
\text { (Kolmogorov- } \\
\text { smirnov }\end{array}$} & \multirow{2}{*}{$\begin{array}{c}\text { Autokorelasi } \\
\text { (Durbin- } \\
\text { Watson) }\end{array}$} \\
\hline & Tolerance & VIF & & \\
\hline KPI & 0,379 & 2,639 & & \\
\hline KPE & 0,376 & 2,657 & & \\
\hline BT & 0,908 & 1,102 & & \\
\hline $\mathrm{BF}$ & 0,963 & 1,038 & & \\
\hline BM & 0,989 & 1,011 & & \\
\hline TA & 0,921 & 1,086 & & \\
\hline \multicolumn{5}{|c|}{ Asymp. Sig (2-tailed) 0,329 } \\
\hline
\end{tabular}

Hasil Uji Regresi Linear Berganda. Hasil analisis regresi berganda disajikan pada Tabel 4.4. Hasil uji model menunjukkan nilai F sebesar 3,618 dengan tingkat signifikansi sebesar $0,003<0,05$. Dengan demikian model penelitian ini layak. Hasil uji t menunjukkan bahwa konsentrasi kepemilikan pada pihak internal berpengaruh negatif pada konservatisma akuntansi. Hal ini berarti semakin tinggi proporsi kepemilikan internal menyebabkan semakin rendah tingkat konservatisma akuntansi.

Konsentrasi kepemilikan oleh pihak eksternal berpengaruh negatif pada tingkat konservatisma akuntansi. Semakin tinggi proporsi kepemilikan pada pihak eksternal menyebabkan semakin tinggi tingkat konservatisma akuntansi. Sedangkan kompetensi spesifik perusahaan yang diukur dengan masa kerja dewan komisaris tidak berpengaruh pada tingkat konservatisma akuntansi. Kompotensi anggota dewan komisaris pada bidang akuntansi/ keuangan tidak berpengaruh pada tingkat konservatisma akuntansi, kompetensi tata kelola yang diukur dengan jabatan rangkap yang dimiliki anggota dewan komisaris pada perusahaan lain juga tidak berpengaruh pada tingkat konservatisma akuntansi.

Ukuran perusahaan diproksikan dengan total aktiva, tidak berpengaruh pada tingkat konservatisma akuntansi. Hasil uji determinasi dengan melihat nilai adjusted $\mathrm{R}^{2}$ menunjukkan bahwa 11,70 persen variansi tingkat konservatisma akuntansi di pengaruhi oleh konsentrasi kepemilikan internal, konsentrasi kepemilikan eksternal, kompetensi spesifik perusahaan anggota dewan komisaris, kompetensi dewan komisaris dibidang akuntansi/keuangan, kompetensi tata kelola anggota dewan komisaris, dan ukuran perusahaan. Sementara itu, 88,30 persen variansi tingkat konservatisma akuntansi dipengaruhi oleh variabel lain yang tidak dimasukkan dalam model penelitian ini.

Selanjutnya dilakukan uji beda t-test tingkat konservatisma akuntansi antara konsentrasi kepemilikan pada pihak internal dan pihak eksternal. Uji t dua sampel independen pada prinsipnya membandingkan rata-rata dua grup yang tidak berhubungan satu dengan yang lainnya, dengan tujuan untuk mengetahui apakah tingkat konsrvatisma 
akuntansi pada konsentrasi kepemilikan internal dan konserntrasi kepemilikan eksternal memiliki rata-rata yang sama ataukah berbeda secara signifikan.

Tabel 4. Hasil Uji Regresi

\begin{tabular}{|c|c|c|c|c|c|}
\hline \multirow[b]{2}{*}{ Variabel } & \multicolumn{2}{|c|}{$\begin{array}{c}\text { Unstandardized } \\
\text { Coefficients }\end{array}$} & \multirow[t]{2}{*}{ Nilai t } & \multirow{2}{*}{$\begin{array}{c}\text { Nilai } \\
\text { Probabilitas }\end{array}$} & \multirow[t]{2}{*}{ Keterangan } \\
\hline & $\beta$ & Std. Error & & & \\
\hline Constant & $-0,134$ & 0,159 & $-0,838$ & 0,404 & \\
\hline KPI & $-0,140$ & 0,039 & $-3,643$ & 0,000 & Signifikan \\
\hline KPE & $-0,133$ & 0,032 & $-4,118$ & 0,000 & Signifikan \\
\hline BT & $-0,002$ & 0,001 & $-1,844$ & 0,680 & Nonsignifikan \\
\hline $\mathrm{BF}$ & $-0,032$ & 0,032 & $-1,006$ & 0,317 & NonSignifikan \\
\hline $\mathrm{BM}$ & $-0,022$ & 0,027 & $-0,833$ & 0,407 & Nonsignifikan \\
\hline TA & 0,009 & 0,006 & 1,614 & 0,109 & Nonsignifikan \\
\hline F Test (sig. 0,003) & 3,618 & & & & \\
\hline Adjusted $\mathrm{R}^{2}$ & 0,117 & & & & \\
\hline
\end{tabular}

Dasar pengambilan keputusan adalah dengan melihat nilai probabilitas dari $\mathrm{F}$ (levene”s test). Jika nilai probabilitas $\mathrm{F} \leq 0,05$, maka $\mathrm{H}_{0}$ ditolak, kelompok adalah berbeda atau variance berbeda. Apabila $\mathrm{H}_{0}$ ditolak, maka dipilih $\mathrm{t}$ yang equal variance not assumed . Akan tetapi, jika nilai probabilitas $\mathrm{F}>0,05$, maka $\mathrm{H}_{0}$ tidak dapat ditolak, jadi variance sama, Apabila $\mathrm{H} 0$ tidak dapat ditolak, maka analisis uji beda harus menggunakan asumsi equal variance assumed dan melihat nilai probabilitas t untuk menentukan signifikansi perbedaan rata-rata. Hasil Uji beda di sajikan pada Tabel 5.

Tabel 5. Hasil Uji Beda Tingkat Konservatisma Akuntansi antara Konsentrasi Kepemilikan Internal dan Konsentrasi Kepemilikan Eksternal

\begin{tabular}{llccccc}
\hline & $\begin{array}{c}\text { Konsentrasi } \\
\text { Kepemilikan }\end{array}$ & $\begin{array}{c}\text { Jumlah } \\
\text { sampel }\end{array}$ & $\begin{array}{c}\text { Nilai } \\
\text { Rata- } \\
\text { rata }\end{array}$ & Nilai t & $\begin{array}{c}\text { Nilai } \\
\text { Proba- } \\
\text { bilitas }\end{array}$ & Keterangan \\
\hline $\begin{array}{c}\text { Konservatisma } \\
\text { Akuntansi }\end{array}$ & Pihak Eksternal & 76 & $-0,022$ & & & \\
Potal & & 44 & $-0,037$ & 0,763 & 0,448 & $\begin{array}{c}\text { Non- } \\
\text { signifikan }\end{array}$ \\
\hline
\end{tabular}

Hasil uji beda (Tabel 5) menunjukkan bahwa nilai rata-rata tingkat konservatisma akuntansi konsentrasi kepemilikan internal sebesar $(-0,037)$ dan konsentrasi kepemilikan eksternal memiliki nilai rata-rata $(-0,022)$. Hasil ini tidak berbeda secara signifikan pada tingkat keyakinan 95 persen. Hasil ini menunjukkan bahwa tidak terdapat perbedaan tingkat konservatisma akuntansi antara konsentrasi kepemilikan Internal dan konsentrasi kepemilikan eksternal.

Berdasarkan analisis data penelitian, berikut diuraikan pembahasan hasil penelitian tentang pengaruh konsentrasi kepemilikan dan kompetensi dewan komisaris pada konservatisma akuntansi. Konsentrasi kepemilikan saham dikelompokkan menjadi kepemilikan oleh pihak internal dan kepemilikan oleh pihak eksternal. Kompetensi dewan komisaris dikelompokkan dalam tiga tipe yaitu kompetensi spesifik perusahaan anggota dewan komisaris, kompetensi dewan komisaris dalam bidang keuangan, dan kompetensi dewan komisaris dalam bidang tata kelola. 
Pengaruh Konsentrasi Kepemilikan Pada Konservatisma Akuntansi. Konsentrasi kepemilikan dalam penelitian ini dikelompokkan dalam dua kelompok yaitu konsentrasi kepemilikan internal dan konsentrasi kepemilikan eksternal. Hasil analisis menunjukkan bahwa konsentrasi kepemilikan internal berpengaruh negatif pada konsenvatisma akuntansi. Hal ini berarti semakin besar proporsi kepemilikan saham terkonsentrasi pada pihak internal perusahaan menyebabkan semakin rendah tingkat konservatisma akuntansi. Hasil analisis sesuai dengan prediksi pada hipotesis 1a (H1a) yang menyatakan bahwa semakin besar proporsi kepemilikan saham terkonsentrasi pada pihak internal perusahaan menyebabkan semakin rendah tingkat Konservatisma akuntansi.

Hasil analisis mengimplikasikan bahwa kepemilkan saham oleh pihak internal (yaitu manajemen, dan anggota keluarga manajemen) menyebabkan semakin rendah tingkat konservatisma akuntansi dan mereka tidak menggunakan konservatisma sebagai alat tata kelola perusahaan. Kepemilkan saham oleh pihak internal atau pemegang saham mayoritas dapat mengurangi konflik keagenan antara manajemen dengan pemegang saham karena pemegang saham memiliki akses langsung tentang informasi privat yang dimiliki oleh manajemen. Sebagai akibatnya, konsentrasi kepemilikan oleh pihak internal kurang memperhatikan kualitas laporan keuangan. Kondisi ini juga didukung oleh argumen efek pembentengan (the entrencment effect) menyatakan bahwa pemegang saham internal menyebabkan rendahnya tingkat konservatisma akuntansi, karena mereka tidak memerlukan konservatisma sebagai alat tata kelola untuk mengontrol prilakunya. Mereka dapat menyembunyikan aktivitas expropriasinya terhadap pemegang saham minoritas.

Hasil penelitian ini sejalan dengan LaFond dan Roychodhury (2008), yang menyatakan bahwa apabila manajer sebagai pemegang saham, maka kepentingannya akan sejalan dengan kepentingan pemegang saham lainnya. Oleh karena itu permintaan akan konservatisma akuntansi sebagai alat untuk memonitor aktivitas manajemen akan berkurang. Karena mereka secara langsung dapat memonitor manajemen sebagai substitusi dari mekanisme tatakelola.

Hipotesis 1b (H1b) menyatakan bahwa semakin besar proporsi kepemilikan saham terkonsentrasi pada pihak eksternal perusahaan menyebabkan semakin tinggi tingkat konservatisma akuntansi. Hasil analisis menunjukkan bahwa konsentrasi kepemilikan saham pada pihak eksternal berpengaruh negatif pada konservatisma akuntansi. Dengan demikian, hasil analisis tidak mendukung hipotesis 1b. Pengaruh negatif konsentrasi kepemilikan saham oleh pihak eksternal pada tingkat konservatisma akuntansi, mengimplikasikan bahwa mereka tidak menerapkan tingkat konservatisma akuntansi yang tinggi untuk mendorong tata kelola perusahaan yang lebih baik. Artinya, konsentrasi kepemilikan oleh pihak eksternal pada perusahaan publik di Indonesia tidak menerapkan peranan tata kelola mereka melalui permintaan tingkat konservatisma akuntansi yang tinggi.

Hasil penelitian ini sesuai dengan hasil penelitian Yonas (2011) yang menemukan bahwa konsentrasi kepemilikan oleh pihak eksternal pada perusahaan publik di Malaysia berpengaruh negatif pada konservatisma akuntansi. Hal ini berarti bahwa pemegang saham mayoritas oleh pihak eksternal tidak secara efektif dalam menerapkan peranan monitoring mereka (Gee, 2008). Hasil penelitian ini sejalan dengan temuan oleh LaFond dan Roychowdhury (2008); Widanaputra (2007); dan Mohamed et al. (2011), yang menyatakan bahwa tingkat kepemilikan manajerial rendah melaporkan laba lebih konservatif dibandingkan dengan tingkat kepemilikan manajerial tinggi. Penelitian ini mengukur konsentrasi kepemilikan oleh pihak eksternal dengan proporsi kepemilikan 
saham oleh pihak selain manajemen dan anggota keluarganya, sehingga dapat dikatakan proporsi kepemilikan manajemen rendah. Hal ini terjadi karena semakin rendah kepemilikan manajerial menyebabkan konflik antara manajemen dan pemegang saham semakin besar, sehingga diperlukan tingkat konservatisma akuntansi lebih tinggi.

Hasil ini menegaskan bahwa konsentrasi kepemilikan saham perusahaan publik di Indonesia kurang mengadopsi tingkat konservatisma akuntansi, baik konsentrasi kepemilikan tersebut pada pihak internal maupun pada pihak eksternal perusahaan. Hal ini berarti investor tidak berperan secara aktif dalam meningkatkan kualitas laporan keuangan melalui penerapan konservatisma akuntansi. Kenyataannya justru semakin tinggi investasi mereka di dalam perusahaan, mengurangi tingkat konservatisma akuntansi. Pengaruh pemegang saham pengendali sangat besar, karena mereka dapat menyembunyikan perilaku oportunistiknya dalam pelaporan keuangan melalui penerapan tingkat konservatisma akuntansi yang lebih rendah.

\section{Pengaruh Kompetensi Dewan Komisaris Pada Konservatisma Akuntansi.} Kompetensi dewan komisaris diproksikan dengan kompetensi spesifik perusahaan, kompetensi dalam bidang akuntansi/ keuangan, dan kompetensi tata kelola. Hipotesis 2a menyatakan bahwa kompetensi spesifik perusahaan anggota dewan komisaris berpengaruh positif pada tingkat konservatisma akuntansi. Hasil analisis menunjukkan bahwa kompetensi spesifik perusahaan tidak berpengaruh pada tingkat konservatisma akuntansi. Hasil ini mengindikasikan bahwa semakin lama dewan komisaris menjabat dalam satu perusahaan tidak meningkatkan kemampuan monitoringnya dan tidak menggunakan konservatisma akuntansi sebagai mekanisma untuk meningkatkan kualitas laporan keuangan.

Perusahaan mungkin memutuskan mempertahankan dewan komisaris karena kemampuan dan kompetensi yang dimiliki oleh anggota dewan komisaris tersebut atau manajemen telah memiliki hubungan yang baik dengan dewan komisaris, sehingga tidak ingin menggantikannya. Fenomena ini konsisten dengan the expertise hypothesis, bahwa semakin lama dewan komisaris menjabat di sebuah perusahaan, dapat meningkatkan pengalaman dan kompetensi spesifik perusahaan dewan komisaris. Akan tetapi, the management-friendliness hypothesis menyatakan bahwa kemungkinan akan muncul risiko, yaitu independensi anggota dewan komisaris akan menurun karena mereka memiliki hubungan kedekatan dengan manajemen (Vafeas, 2003). Dewan komisaris yang realtif lama bekerja di perusahaan dapat dipengaruhi oleh manajemen, apalagi perusahaan di Indonesia dimiliki oleh pemegang saham pengendali. Dewan komisaris dapat membantu pemegang saham pengendali mengejar kepentingan pribadinya,.

Kompetensi dewan komisaris pada bidang akuntansi/keuangan tidak berpengaruh pada konservatisma akuntansi. Hasil analisis tidak sesuai dengan hipotesis $2 \mathrm{~b}$, yang menyatakan semakin besar proporsi dewan komisaris yang memiliki kompetensi dalam bidang akuntansi/keuangan, menyebabkan semakin tinggi tingkat konservatisma akuntansi. Besarnya proporsi dewan komisaris yang memiliki kompetensi dibidang akuntansi/ keuangan tidak menjamin pengawasan yang dilakukan oleh dewan komisaris lebih ketat, dengan menerapkan akuntansi yang konservatif untuk mencegah perilaku oportunistik manajer. Hasil ini juga didukung oleh data yang menggambarkan ada perusahaan yang anggota dewan komisarisnya tidak memiliki kompetensi dibidang akuntansi /keuangan. 
Hipotesis 2c (H2c) menyatakan semakin tinggi proporsi dewan komisaris yang memiliki kompetensi di bidang tata kelola perusahaan menyebabkan semakin rendah tingkat konservatisma akuntansi. Hasil analisis menunjukkan bahwa konpetensi dewan komisaris pada bidang tata kelola perusahaan tidak berpengaruh pada konservatisma akuntansi. Ada dua arumen yang saling bertentangan tentang jabatan rangkap dewan komisaris pada perusahaan lain. Argumen pertama menyatakan bahwa semakin tinggi proporsi dewan komisaris yang memiliki jabatan rangkap, maka mereka semakin sibuk dan semakin luas pengetahuannya tentang tata kelola perusahaan. Akan tetapi, argumen kedua menyatakan bahwa anggota dewan komisaris yang memiliki jabatan rangkap, akan melayani banyak perusahaan dan mereka tidak efektif dalam mentransfer pengetahuannya ke dalam satu perusahaan.sehingga semakin rendah tingkat konservatisma akuntansi.

Hasil analisis membuktikan bahwa kompetensi dewan komisaris, bukan penentu utama dari penyajian kualitas laporan keuangan melalui adopsi konservatisma akuntansi. Hasil ini sejalan dengan Ujiyantho dan Pramuka (2007) menyatakan bahwa jumlah dewan komisaris tidak berpengaruh pada manajemen laba, karena besar kecilnya dewan komisaris bukanlah faktor penentu utama efektivitas pengawasan terhadap manajemen perusahaan. Akan tetapi, efektivitas mekanisme pengendalian tergantung pada nilai, norma dan kepercayaan yang diterima dalam suatu organisasi serta peran dewan komisaris dalam aktivitas monitoring terhadap manajemen laba.

Ukuran perusahaan tidak berpengaruh pada tingkat konservatisma akuntansi. Hasil ini tidak mendukung prediksi yang menyatakan bahwa ukuran perusahaan menyebabkan perusahaan menerapkan konservatisma akuntansi. Artinya, ukuran perusahaan tidak dapat berfungsi untuk mengontrol hubungan kausalitas antara konsentrasi kepemilikan internal, konsentrasi kepemilikan eksternal, masa kerja dewan komisaris, kompetensi dewan komisaris pada bidang akuntansi/ keuangan, dan jabatan rangkap dewan komisaris di perusahaan lain dan tingkat konservatisma akuntansi. Hasil penelitian ini tidak mampu menegaskan penelitian Sari (2005) dan Widanaputra (2007) yang menebukan bahwa perusahaan memilih penerapan konservatisma akuntansi untuk meminimalkan laporan laba sehingga perhatian pemerintah terhadap perusahaan akan berkurang.

\section{PENUTUP}

Simpulan. Hasil penelitian ini menunjukkan bahwa: (1) konsentrasi kepemilikan di pihak internal berpengaruh negatif pada tingkat konservatisma akuntansi; (2) Konsertrasi kepemilikan pada pihak eksternal berpengaruh negatif pada tingkat konservatisma akuntansi. Hal ini sejalan dengan positive accounting theory yang menyatakan bahwa perusahaan menerapkan konservatisme akuntansi untuk mengurangi konflik keagenan, akan tetapi hasil penelitian ini mengindikasikan bahwa keputusan untuk menerapkan konservatisma akuntansi ditetapkan oleh pemegang saham pengendali; (3) Kompetensi spesifik-perusahaan dewan komisaris tidak berpengaruh pada tingkat konservatisma akuntansi; (4) Kompetensi dewan komisaris dalam bidang akuntansi/ keuangan tidak berpengaruh pada tingkat konservatisma akuntansi, dan (5) Kompetensi tata kelola dewan komisaris tidak berpengaruh pada konservatisma akuntansi. Dengan demikian, teori ketergantungan sumber daya (resource dependence theory) tidak didukung oleh data penelitian ini. Anggota dewan komisaris cenderung tidak menggunakan konservatisma akuntansi untuk mengelola ketergantungan pihak eksternal, mengurangi ketidakpastian lingkungan dan interdependensi lingkungan. 
Saran. Bagi peneliti selanjutnya, penelitian ini memiliki kontribusi pemahaman bahwa konsentrasi kepemilikan dapat mengurangi tingkat konservatisma akuntansi yang di adopsi perusahaan. Akan tetapi, penelitian ini memiliki beberapa keterbatasan antara lain seperti berikut: (1) Sampel penelitian tidak menyertakan perusahaan non manufaktur (perusahaan keuangan), karena perusahaan keuangan memiliki tingkat regulasi yang lebih tinggi dibandingkan perusahaan manufaktur. Dengan demikian hasil penelitian ini tidak bisa digeneralisasi untuk selain perusahaan manufaktur. Penelitian selanjutnya disarankan memperluas penelitian ini untuk perusahaan finansial; (2) Penelitian ini hanya menguji mekanisma corporate governance yang terdiri dari konsentrasi kepemilikan dan dewan komisaris. Kedua mekanisma ini terkait dengan pengawasan dan akuntabilitas. Sementara, konservatisma akuntasi yang diadopsi oleh perusahaan kemungkinan besar dilakukan oleh manajemen perusahaan (corporate management). Penelitian berikutnya diharapkan menguji corporate managemen seperti komposisi manajemen perusahaan dan komite audit; (3) Pengukuran konservatisma akuntansi dalam penelitian ini menggunakan model akrual, penelitian berikutnya disarankan untuk menggunakan model pasar (asymmetric timeliness) untuk mengukur konservatisma akuntansi.

\section{DAFTAR RUJUKAN}

Ahmed, A. S., Billing, B. K., Morton, R. M., dan Stanford-Harris, M. (2002) “The Role of Accounting Conservatism in Mitigating Bondholders and Shareholders Conflicts over Dividends Policy and in Reducing Debt Cost”. The Accounting Review 77 (4): 867- 890.

Ahmed, A.S. dan Duellman, S. (2006) Accounting Conservatism and Board of Director Characteristic: An Empirical Analysis. http://ssrn.com. 30 Juni 2011.

Ahmed, A. S., Morton, R. M., dan Schaefer, T. F. (2000) "Accounting Conservatism and Valuation of Accounting Numbers: Evidence of the Feltham-Ohlson (1996) Model”. Journal of Accounting, Auditing \& Finance, 15 (3): 271-292.

Ball, R. dan Shivakumar, L., (2005) "Earnings Quality in U.K. Private Firms: Comparative Loss Recognition”. Journal of Accounting and Economics 38: 83-128.

Basu, S. (1997) "The Conservatism Principle and The Asymmetric Timeliness of Earnings”. Journal of Accounting and Economics 29 (February): 1-51.

Beaver, W. H. dan Ryan, S. G. (2000) "Biases and Lags in Book Value and Their Effects on The Ability of The Book-to-Market Ratio to Predict Book Return on Equity”. Review of Accounting Research 38 (1): 127-48.

Beaver, W. H. dan Ryan, S. G. (2005) "Conditional and Unconditional Conservatism: Concepts and Modeling”. Review of Accounting Studies 10: 269-309.

Claessens, S. dan Fan, J. P. H. (2002) "Corporate Governance in Asia: A Survey". International Review of Finance 3 (2): 71-103.

Claessens, S., Djankov, S., Fan, J. P. H., dan Lang, L. H. P. (1999) Expropriation of Minority Shareholders: Evidence from East Asia. Working Paper. World Bank.

Claessens, S., Djankov, S., Lang, L. H. P. (2000) "The Separation of Ownership and Control in East Asia Corporations”. Journal of Financial Economic, 58: 81-112.

Crutchley dan Hansen. (1989) A Test of Agency Theory of Managerial Ownership, Corporate Leverage and Corporate Dividends. Financial Management (Winter): 3646. 
Dargenidou, C., Mc.Leay, S., dan Raonic, I. (2007) "Ownership, Investor Protection and Earnings Expectations”. Journal of Business Finance \& Accounting, 34 (1/2): 247268.

Deloof, M., Rogeman, A dan Overfelt, W.V. (2006) Who's Afraid of Universal Banks? Universal Bank Affiliation and Corporate Dividend Policy in Pre-World War I Belgium, Working Papers. University.

Fan, J. P. H dan Wong, T. J. (2002) "Corporate Ownership Structure and The Informative of Accounting Earnings in East Asia”. Journal of Accounting and Economics, 33: 401- 425.

Febrianto, R. (2005) “The Effect of Ownership Concentration on The Earnings Quality: Evidence from Indonesian Companies”. Jurnal Riset Akuntansi Indonesia, 8 (2):105-120 .

Gilson, R. J. (2006) Controlling Shareholders and Corporate Governance: Complicating The Comparative Taxonomy. Harvard Law Review, 119: 1641-1679.

Givoly, D. dan Hayn, C. (2000) “The Changing Time-series Properties of Earnings, Cash Flow and Accruals: Has Financial Reporting Become More Conservative?” Journal of Accounting and Economics, 12: 97-123.

Hille, J. C. (2011) Accounting Conservatism. Working Paper http://ssrn.com. 20 Oktober.

Jensen, M. C dan Meckling, W. H. (1976) "Theory of The Firm: Managerial Behavior, Agency Cost and Ownership Structure”. Journal of Financial Economics, 3 (4): 305360.

Jensen, M.C. (1993) "The modern industrial revolution, exit, and the failure of internal control systems". The Journal of Finance, 48 (3), 831-880

LaFond, R. dan Roychowdhury, S. (2008) "Manajerial Ownership and Accounting Conservatism”, Journal of Accounting Research, 46 (1): 101-135.

La Porta, R., Lopez-de-Silanes, F., Shleifer, A. (1999) "Corporate Ownership Around the World”. Journal of Finance, 54 (2): 471-517.

Lanfranconi, CP., dan Roberrtson DA. (2002) "Corporate financial reporting: The role of the board directors”, Ivey Business Journal, 67 (1): 1-3

Leuz, C., Nanda, D., dan Wysocki P. D. (2003) "Earnings Management and Investor Protection: An International Comparison”. Journal of Financial Economic, 69: 505527.

Morck, R., Wolfenzon, D., dan Yeung, B. (2004) Corporate Governance Economic Entrenchment, and Growth. NBR Working Paper No. 10692.

Nikolaev, V. V. (2010) “Debt Covenants and Accounting Conservatism”. Journal of Accounting Research, 48 (1):137-176.

Ratnadi, NMD.,Sutrisno T.,Achsin, M., Mulawarman, AD. (2013) "The Effectof shareholder' Conflict over devidend Policy on Accounting Consevatism: Evidence from Public Firms in Indonesia”. Research Journal of Finance and Accounting. 4 (6).

Roychowdhury, S. dan Watts, R. L. (2006) “Asymmetric Timeliness of Earnings, Marketto-Book and Conservatism in Financial Reporting”. Journal of Accounting and Economic.

Pfeffer, J dan Salancik, G.R. (2003) The external control of organizations: A resource dependence perspective. California: Stanford University Press.

Sanjaya, P. S. (2010) "Efek Entrenchment dan Alignment pada Manajemen Laba". SNA XIII Purwokerto; 13-14 Oktober. 
Shleifer, A. dan Vishny, R.W. (1997) “A Survey of Corporate Governance”. The Journal of Finance, LII (2): 737-783.

Siregar, B. (2006) "Pemisahan Hak Aliran Kas dan Hak Kontrol dalam Struktur Kepemilikan Ultimat”. Disertasi. Program Doktor Akuntansi Fakultas Ekonomi, Universitas Gajah Mada.

Sterling, R. (1967) Conservatism: The Fundamental Principles of Valuation in Traditional Accounting. Abacus, 3: 109-132.

Suwardjono. (2005) Teori Akuntansi Perekayasaan Pelaporan Keuangan. Edisi Ketiga.Yogyakarta: BPFE

Ujiyantho dan Pramuka, (2007) "Mekanisme Corporate Governance, Manajemen Laba dan Kinerja Keuangan (Studi Pada Perusahaan go publik Sektor Manufaktur)", Simposium Nasional Akuntansi X, Makasar.

Watts, L.R. dan Zimmerman, J. L. (1986) Positive Accounting Theory. Prentice Hall, Inc., Englewood Cliffs, New Jersey 07632.

Watts, L. R. (2003a) Conservatism in Accounting Part I: Explanations and Implications. Accounting Horizons, 17 (3): 207-221.

Zhang, J. (2008) "The Contracting Benefits of Accounting Conservatism to Lenders and Borrowers”. Journal of Accounting and Economics, 45: 27-54.

Yunos. R. M., Smith, M., dan Ismail, Z. (2010) "Accounting Conservatism and Ownership Concentration: Evidence From Malaysia”. Journal and Policy Research, 5 (2): 1-15. 